\title{
Pregnant women's working conditions and their changes during pregnancy: a national study in France
}

\author{
M J SAUREL-CUBIZOLLES, M KAMINSKI \\ From INSERM Unité 149, 94807, Villejuif Cedex, France
}

ABSTRACT In a study of 2387 employed women who had worked for more than three months of their pregnancy the data were extracted from a survey carried out on a national sample of births ig France in 1981. Manual, service and shop workers had a higher preterm delivery rate than profes-sional, administrative, or clerical workers. Assembly line work was associated with a higher preternt delivery rate even when production workers only were considered. Cumulated physically tirinis working conditions - standing work, carrying of heavy loads, assembly line work, and considerab局 physical effort-were related to higher preterm delivery and low birthweight rate. During preg nancy, sickness absences were commoner when the working conditions were arduous. Changes int the working conditions were less clearly related to arduous work than sick leaves; they were net significantly more frequent for standing work or for assembly line work. Refusals from employers. to grant favourable arrangements were more frequent when the working conditions were tiring an $\bar{\phi}_{\infty}$ sick leaves were more common among women whose requests had been refused.

Whereas during the 1950s and 1960s several authors have shown that paid work of pregnant women was a risk for the outcome of pregnancy, nowadays in western countries working pregnant women do not register less favourable perinatal outcomes; on the contrary, some studies have established that the preterm delivery rate of those women is lower than that of non-working women. ${ }^{1}$ Nevertheless, the relation between physically arduous working conditions and outcome of pregnancy, in particular a higher preterm delivery rate, has often been reported. ${ }^{2-5}$

Since 1975, changes in working conditions in France have been provided for in the "Code du Travail" for pregnant employees. At the request of the women themselves or of their employer and if the occupational physician agrees a change of post may occur without any loss in wages; if this transfer occurs at the women's request she must have worked for one year in the firm to maintain the same wage. ${ }^{6}$ This possibility applies to each employee and may be complemented by measures specific to certain industry group agreements allowing some changes in pregnant women's working practices such as shorter working hours, additional breaks, or reduction in the required output.

Accepted 28 May 1986
The present study shows how the outcome of preg nancy was related to working conditions in France ing 1981 and analyses how far changes in working condi-D tions and absence from work concern pregnant women in the most strenuous jobs.

\section{Population and methods}

This study is based on data from a survey carried outo by the Institut National de la Santé et de la Recherche Médicale on a national sample of births in France in $1981 .{ }^{7}$ France was divided into 12 geographical areas and the survey in each area was completed in 20 days $ᄋ$ A two stage random sampling scheme was used, firstly, drawing a sample of maternity units, after stratification according to the geographical area, the $p$ maternity sector (private or public), and the numbere. of beds; and, secondly, in the selected units drawing an sample of births so that the total sampling fraction was $1 / 8$ in each area during the study period.

Women were interviewed in hospital within sixce days of delivery, using a standardised questionnaire $\sigma$ Information about obstetrical history, antenatal careso and course of pregnancy was also collected whereasD data about confinement and child's health at birth $\stackrel{\text { ? }}{-}$ were abstracted from the medical records of the hos- -0 pitals. In all, 5508 women were interviewed, 2955 of whom had had paid work at some stage of their pregnancy. 
The study was limited to employees; 245 selfemployed women and 39 women whose employment status was unknown were excluded. The following groups of women were also excluded: women who had worked one trimester only during their pregnancy: 251 women among whom 239 had worked during the first trimester only, 12 who had worked during the second and third trimester only, six who had worked during the first and the third trimester but not during the second, and 15 for whom detailed information was missing. Finally, the study was confined to 2387 employees who had worked during the first trimester of pregnancy and after.

Two indicators of outcome of pregnancy were selected: preterm delivery occurring before 37 completed weeks of amenorrhoea and birth weight below $2500 \mathrm{~g}$. The occupations were coded according to the National Institute of Statistics and Economic Studies (INSEE) classification for socioprofessional categories used in France in $1981 .^{8}$ This code clusters occupations in a slightly different way from the one used in the United Kingdom. For this study, two occupational groups have been considered: one included occupations known as risk factor of preterm delivery-production, service, and shop workers ${ }^{9}$ - whereas the other included professional, administrative, and clerical workers.

Working conditions during the first trimester of pregnancy such as had been described by the women were taken into account in this analysis as well as any modifications that occurred during pregnancy. Sickness absences have been described by their frequency and their cumulated duration during pregnancy as well as by the percentage of women who did not work at all during the third trimester, whatever the reason for the interruption of work may have been. Changes in working conditions have been described by their frequency and their nature and the reasons explaining why some women did not have the benefit of them have been reported. Pregnancy diseases or abnormalities were taken into account to analyse the absences from work; various abnormalities were listed-hypertension $(\max >14$ or $\min >$ 9), albuminuria, oedema, urinary infection, vulvovaginitis, metrorrhagia, threatened preterm delivery, diabetes, or other abnormalities. The data were analysed separately for women who reported none and for those who had mentioned at least one.

Outcome of pregnancy was compared according to working conditions; occupation was also considered since there is a strong relation between type of occupation and working conditions. Other characteristics were also taken into account by means of an adjusted test when they were related to the outcome of pregnancy; parity and smoking were thus considered in the frequency of low birth weight. ${ }^{9-10 a}$
Changes in working conditions and absences from work were analysed in relation to working conditions; the frequency and the duration of sickness absences were observed depending on whether women had or had not benefited from favourable arrangements of their working conditions.

The statistical methods used were Pearson's chi square test and the analysis of variance. The method of Mantel and Haenszel was used to adjust for confounding factors and the test of Boyd and Doll for a risk factor in more than two classes, such as the combination of several working conditions.

\section{Results}

\section{WORKING CONDITIONS AND OUTCOME OF} PREGNANCY

Among employees who worked beyond the first trimester of pregnancy, $39 \%$ belonged to the group of manual occupations; production workers $21 \%$, service workers $12 \%$, and shop assistants $6 \%$. The second group included professional $7 \%$, managerial and teachers $19 \%$, and clerical workers $35 \%$. The working conditions were as follows: $35 \%$ of the women stood for most of the time, $15 \%$ had to carry heavy loads, $7 \%$ were assembly line workers, and, on the whole, $23 \%$ had a physically demanding job. When these four working conditions were cumulated, $10 \%$ of employees were exposed to at least three of them. Four per cent of women worked at night, always or occasionally, and $9 \%$ worked 42 hours or more a week.

These working conditions were strongly related to the type of occupation: assembly line work was carried out by production workers only, standing work was common for all occupations except for clerical staff, and the carrying of heavy loads and physical effort were the most frequent for production, shop, and service workers. Thereby, $3 \%$ of professional, administrative, or clerical workers were concerned with the accumulation of three or four of the difficult working conditions, compared with $22 \%$ among production, shop, and service workers.

Preterm delivery was significantly more frequent among production, shop, and service workers, $7 \%$ compared with $4 \%$ among professional, administrative, or clerical staff $(p<0.01)$. No significant link was found between occupation and low birth weight.

Assembly line workers more frequently had a preterm delivery than other women (table 1); this relation was also significant among manual workers only. All women who cumulated three or four of the working conditions - standing position, heavy load carrying, assembly line work, and physically demanding work-had a significantly higher preterm delivery rate $(8 \%)$ than women who had none of these condi- 
Table 1 Pregnancy outcome according to working conditions

\begin{tabular}{|c|c|c|c|c|}
\hline \multirow{2}{*}{$\begin{array}{l}\text { Occupation and working } \\
\text { conditions during first trimester }\end{array}$} & \multicolumn{2}{|c|}{$\begin{array}{l}\text { Preterm } \\
\text { delivery }\end{array}$} & \multicolumn{2}{|c|}{$\begin{array}{l}\text { Birth weight } \\
<2500 \mathrm{~g}\end{array}$} \\
\hline & No & $\%$ & No & $\%$ \\
\hline \multicolumn{5}{|l|}{ Occupation: } \\
\hline $\begin{array}{l}\text { Production, service, and shop } \\
\text { workers } \\
\text { Professional, administrative }\end{array}$ & 880 & $6 \cdot 6_{* *}$ & 942 & $5 \cdot 0$ NS \\
\hline and clerical workers & 1381 & 3.7 & 1451 & $4 \cdot 1^{100}$ \\
\hline Standing position: & & & & \\
\hline $\begin{array}{l}\text { Yes } \\
\text { No }\end{array}$ & $\begin{array}{r}780 \\
1489\end{array}$ & $\begin{array}{l}5 \cdot 6 \\
4 \cdot 4\end{array}$ & $\begin{array}{r}832 \\
1568\end{array}$ & ${ }_{4 \cdot 3}^{4 \cdot 8} \mathrm{NS}$ \\
\hline \multicolumn{5}{|l|}{ Heavy load carrying: } \\
\hline $\begin{array}{l}\text { Yes } \\
\text { No }\end{array}$ & $\begin{array}{r}328 \\
1934\end{array}$ & ${ }_{4.6}^{6.1} \mathrm{NS}$ & $\begin{array}{r}352 \\
2039\end{array}$ & $\begin{array}{l}5 \cdot 7 \\
4 \cdot 2\end{array}$ \\
\hline \multicolumn{5}{|l|}{ Assembly line work: } \\
\hline $\begin{array}{l}\text { Yes } \\
\text { No }\end{array}$ & $\begin{array}{r}159 \\
2111\end{array}$ & $\begin{array}{l}9 \cdot 4 \\
4 \cdot 5\end{array}$ & $\begin{array}{r}171 \\
2231\end{array}$ & ${ }_{4 \cdot 4}^{5 \cdot 3} \mathrm{NS}$ \\
\hline \multicolumn{5}{|l|}{ Considerable physical effort: } \\
\hline $\begin{array}{l}\text { Yes } \\
\text { No }\end{array}$ & $\begin{array}{r}525 \\
1737\end{array}$ & $\begin{array}{l}5 \cdot 5 \\
4 \cdot 6\end{array}$ & $\begin{array}{r}553 \\
1836\end{array}$ & $\begin{array}{l}6 \cdot 3 * \\
4 \cdot 0\end{array}$ \\
\hline \multicolumn{5}{|c|}{ Combination of the four above working conditions: } \\
\hline $\begin{array}{l}3 \text { or } 4 \\
1 \text { or } 2 \\
\text { None }\end{array}$ & $\begin{array}{r}232 \\
805 \\
1218\end{array}$ & $\begin{array}{l}8 \cdot 2 \\
5 \cdot 1^{*} \\
4 \cdot 0\end{array}$ & $\begin{array}{r}248 \\
848 \\
1284\end{array}$ & $\begin{array}{l}8 \cdot 5 \\
3 \cdot 2^{* *} \\
4 \cdot 5\end{array}$ \\
\hline \multicolumn{5}{|l|}{ Night work: } \\
\hline $\begin{array}{l}\text { Yes } \\
\text { No }\end{array}$ & $\begin{array}{r}77 \\
2184\end{array}$ & $\begin{array}{l}3.9 \\
4.8\end{array}$ & $\begin{array}{r}90 \\
2302\end{array}$ & ${ }_{4 \cdot 4}^{5 \cdot 6} \mathrm{NS}$ \\
\hline \multicolumn{5}{|l|}{ Weekly working hours: } \\
\hline $\begin{array}{l}\geqslant 42 \\
<42\end{array}$ & $\begin{array}{r}198 \\
2047\end{array}$ & $\begin{array}{l}3.0 \\
5 \cdot 0\end{array}$ & $\begin{array}{r}206 \\
2169\end{array}$ & $\begin{array}{l}4 \cdot 4 \\
4 \cdot 5\end{array}$ \\
\hline
\end{tabular}

Employees who have worked at least partly during the first two trimesters of pregnancy.

*Statistically significant at 0.05 level; **at 0.01 level.

tions $(4 \%)$ or one or two $(5 \%)$. This difference was no longer significant after adjustment for occupation; nevertheless, in the group of manual workers the preterm birth rate was $4 \%$ among women who had none of these conditions and $10 \%$ among women who cumulated three or four of these working conditions (table 2). The low birthweight rate was higher among women who had to make a considerable physical effort and among women who cumulated more than two strenuous working conditions, and this remained significant after adjusting for occupation. Both relations remained significant when parity, smoking habits, and preterm delivery were taken into account. No relation was observed between the outcome of pregnancy and night work or the weekly working hours.

WORKING CONDITIONS, ABSENCES FROM WORK, AND CHANGES OF WORK DURING PREGN.ANCY

For the four strenuous working conditions, mentioned above, the proportion of women who did not work at all during the third trimester was higher when the work was strenuous (table 3). Reasons for the absences from work were various but, apart from the legal prenatal leave, sick leaves were the most frequent; they were commoner or longer when the work was physically tiring. When the working conditions were tiring, a higher proportion of women took sick leave or did not work at all during the third trimeste? and this was observed even among women who ha零 no disease or abnormality during pregnancy.

For women who had to carry heavy loads, make physical efforts, or who cumulated several strenuous. working conditions, changes in job were more com? mon than for other women. But they were no? significantly more frequent for women who workeक while standing or on an assembly line (table 4). Wherb the type of modification was considered, shorter working hours-more breaks or shorter working $\overrightarrow{\text { g }}$ day-were not more frequent when the working cono ditions were tiring. On the contrary, shorter working hours were significantly less common for women working 42 hours or more a week. Women with tiring working conditions were more often able to sit, $\mathrm{al}_{\tilde{N}}^{+}$ though only $22 \%$ of the women who stood at work were affected by this improvement. A reduction in the required output was more often allowed for assembly line workers, although only $20 \%$ benefited from this (table 4). For the women who obtained no favourable change in their working conditions, there was a re lation between the reasons for this and the initiabo working conditions. The proportions of women whose employer refused a change in working condi tions or who thought such changes impossible were higher among women having difficult working condi $\bar{\partial}$ tions. By contrast, as expected, women who considy ered such changes unnecessary were more numerous when the working conditions were not tiring (table 5) The same relation was observed between working conditions and sick leave or changes of work in both groups of occupations.

Table 2 Pregnancy outcome related to working conditions according to women's occupation

\begin{tabular}{|c|c|c|c|c|}
\hline \multirow{2}{*}{$\begin{array}{l}\text { Occupation and combination } \\
\text { of the four working conditions }\end{array}$} & \multicolumn{2}{|c|}{$\begin{array}{l}\text { Preterm } \\
\text { delivery }\end{array}$} & \multicolumn{2}{|c|}{$\begin{array}{l}\text { Birth weight } \\
<2500 \mathrm{~g}\end{array}$} \\
\hline & No & $\%$ & $N o$ & $\%$ \\
\hline
\end{tabular}

Production, service, and shop workers:

+3 or 4

1 or 2

None

Professional, administrative, and

clerical workers:

+3 or 4

1 or 2

None

Adjustment for group of

occupations

$\begin{array}{llll}193 & 9.8 & 207 & 8.7 \\ 495 & 6.3 \mathrm{NS} & 526 & 3.6 \\ 180 & 4.4 & 191 & 4.7\end{array}$

Employees who have worked at least partly during the first two trimesters of pregnancy.

*Statistically significant at 0.05 level; **at 0.01 level.

tCombination of the four working conditions: standing position heavy load carrying, assembly line work, considerable physical effort. 
Table 3 Absence from work during pregnancy according to working conditions

\begin{tabular}{|c|c|c|c|c|c|c|}
\hline \multirow[b]{2}{*}{ Working conditions during first trimester } & \multicolumn{2}{|c|}{$\begin{array}{l}\text { Women who have had at least } \\
\text { one sick leave }\end{array}$} & \multicolumn{2}{|c|}{$\begin{array}{l}\text { Mean No of days of sick leave } \\
\text { per women who have had at } \\
\text { least one sick leave }\end{array}$} & \multicolumn{2}{|c|}{$\begin{array}{l}\text { Women who have stopped } \\
\text { working before third trimester }\end{array}$} \\
\hline & No & $\%$ & No & No of days & No & $\%$ \\
\hline \multicolumn{7}{|l|}{ Standing position: } \\
\hline $\begin{array}{l}\text { Yes } \\
\text { No }\end{array}$ & $\begin{array}{r}797 \\
1514\end{array}$ & $\begin{array}{l}63 \cdot 6 \\
61 \cdot 6\end{array}$ & $\begin{array}{l}482 \\
886\end{array}$ & $\begin{array}{l}41 \\
35\end{array}$ & $\begin{array}{r}823 \\
1551\end{array}$ & $\begin{array}{l}21 \cdot 8 * * * \\
14 \cdot 8\end{array}$ \\
\hline \multicolumn{7}{|l|}{ Heavy load carrying: } \\
\hline $\begin{array}{l}\text { Yes } \\
\text { No }\end{array}$ & $\begin{array}{r}334 \\
1971\end{array}$ & $\begin{array}{l}70 \cdot 7 \\
61 \cdot 0\end{array}$ & $\begin{array}{r}225 \\
1141\end{array}$ & $\begin{array}{l}45 \\
36\end{array}$ & $\begin{array}{r}347 \\
2019\end{array}$ & $\begin{array}{l}24 \cdot 8 * * * \\
16 \cdot 1\end{array}$ \\
\hline \multicolumn{7}{|l|}{ Assembly line work: } \\
\hline $\begin{array}{l}\text { Yes } \\
\text { No }\end{array}$ & $\begin{array}{r}165 \\
2147\end{array}$ & $\begin{array}{l}77 \cdot 0 \\
61 \cdot 2\end{array}$ & $\begin{array}{r}112 \\
1256\end{array}$ & $\begin{array}{l}46 \\
37\end{array} * * *$ & $\begin{array}{r}171 \\
2205\end{array}$ & $\begin{array}{l}26 \cdot 3 * * * * \\
16 \cdot 6\end{array}$ \\
\hline \multicolumn{7}{|l|}{ Considerable physical effort: } \\
\hline $\begin{array}{l}\text { Yes } \\
\text { No }\end{array}$ & $\begin{array}{r}528 \\
1775\end{array}$ & $\begin{array}{l}70 \cdot 6 \\
59 \cdot 9 * * *\end{array}$ & $\begin{array}{r}353 \\
1012\end{array}$ & $44 * * *$ & $\begin{array}{r}547 \\
1816\end{array}$ & $\begin{array}{l}25 \cdot 6 \\
14 \cdot 8 * * *\end{array}$ \\
\hline \multicolumn{7}{|l|}{ Combination of the four above working } \\
\hline $\begin{array}{l}3 \text { or } 4 \\
1 \text { or } 2 \\
\text { None }\end{array}$ & $\begin{array}{r}237 \\
817 \\
1242\end{array}$ & $\begin{array}{l}74 \cdot 7 \\
63 \cdot 6 * * * \\
59 \cdot 3\end{array}$ & $\begin{array}{l}168 \\
490 \\
704\end{array}$ & $\begin{array}{l}44 \\
41 * * * \\
34\end{array}$ & $\begin{array}{r}245 \\
841 \\
1269\end{array}$ & $\begin{array}{l}27 \cdot 8 \\
19 \cdot 0 * * * \\
14 \cdot 1\end{array}$ \\
\hline \multicolumn{7}{|l|}{ Night work: } \\
\hline Yes & $\begin{array}{r}87 \\
2217\end{array}$ & $\begin{array}{l}62 \cdot 1 \\
62 \cdot 4\end{array}$ & $\begin{array}{r}51 \\
1314\end{array}$ & $\begin{array}{l}47 \\
37\end{array}$ NS & $\begin{array}{r}88 \\
2278\end{array}$ & $\begin{array}{l}25 \cdot 0 \\
17 \cdot 0\end{array}$ \\
\hline $\begin{array}{l}\text { Weekly working hours: } \\
\geqslant 42 \\
<42\end{array}$ & $\begin{array}{r}198 \\
2092\end{array}$ & $\begin{array}{l}60 \cdot 1 \\
62 \cdot 9\end{array}$ & $\begin{array}{r}116 \\
1247\end{array}$ & $\begin{array}{l}39 \\
37\end{array}$ NS & $\begin{array}{r}205 \\
2142\end{array}$ & $\begin{array}{l}22 \cdot 4 \\
16 \cdot 9\end{array}$ \\
\hline
\end{tabular}

Employees who have worked at least partly during the first two trimesters of pregnancy.

*Statistically significant at 0.05 level; ${ }^{* *}$ at 0.01 level; ${ }^{* * *}$ at 0.001 level.

Table 4 Modifications of work during pregnancy according to working conditions

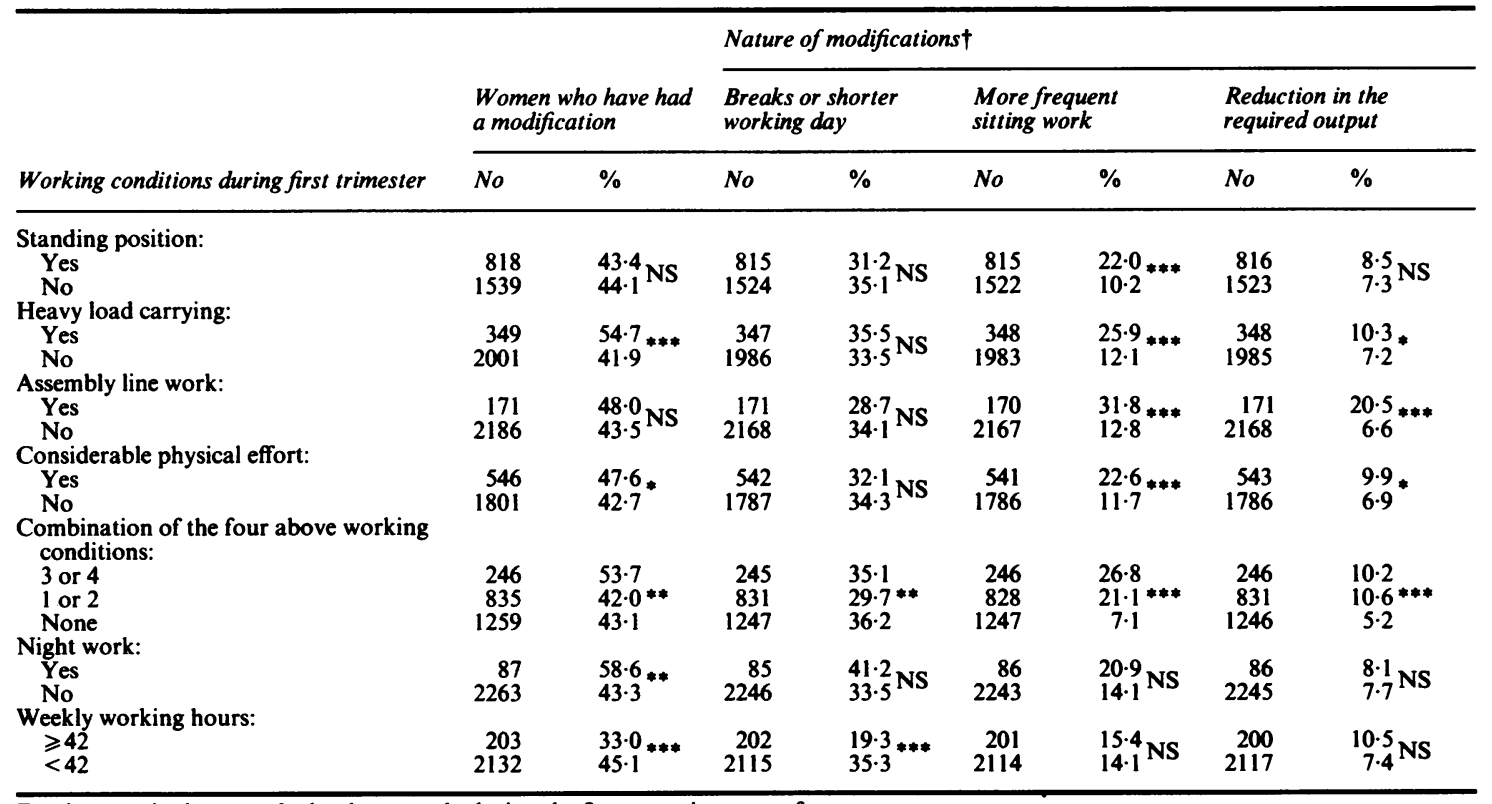

Employees who have worked at least partly during the first two trimesters of pregnancy.

tWomen can cumulate several modifications.

*Statistically significant at 0.05 level; ${ }^{* *}$ at 0.01 level; ***at 0.001 level. 
ities arising during or at the outcome of pregnancy might have an impact on the way women described their working conditions and their arrangements; it was not possible to assess this phenomenon.

In France the benefits offered to pregnant employees do not usually exist for self employed women. Even if, for a few years, women farmers and shop keepers have been able to qualify for replacement allowances to enable them to stop their occupational activity for four weeks and to have a substitute for their job at the time of confinement they do not have the benefit of sick leave allowances during pregnancy. There are also no legal provisions for changes in working conditions as there are for employees. Since we particularly focused on sickness absences and changes in working practices, it was necessary to confine our study to the employee population, which is more homogeneous in this respect.

Women who worked during the first trimester only were excluded from the analysis because they presented risk factors previous to this pregnancyhigher rate of previous abortions or preterm deliveries-which might have modified the relation between working conditions and outcome of pregnancy. Moreover, since their work was only at the beginning of pregnancy it would not have been possible to relate their working conditions to a possible preterm delivery. For reasons of homogeneity we excluded the few women who worked sporadically or who began to work after the first trimester of pregnancy.

The working conditions of the first trimester were analysed because they are the most descriptive of the women's occupation before any application of possible arrangements related to pregnancy; These arrangements were taken into account and examined as the women reported them. Consequently some women may have been considered as exposed to arduous working conditions, although they rapidly benefited from a modification in their work: this may lead to an underestimate in the frequency of unfavourable outcomes in the group of women with arduous working conditions. By contrast, by considering the working conditions during the second or third trimester, we were likely to eliminate some women who had been relieved of tiresome work for medical reasons and thus to overestimate the frequency of unfavourable outcomes in the group of women who did not experience arduous working conditions. In fact, we have observed that, when women continued their occupational activity throughout pregnancy, the changes were rarely important enough to allow the working conditions to be reported as different from one trimester to the other.

Assembly line work was associated with a significantly higher percentage of preterm deliveries even when production workers only were considered in order to compare groups of similar social backgrounds. The percentage of infants weighing less than $2500 \mathrm{~g}$ was higher when the mothers had a physically demanding job even taking into account parity and smoking habits.

Cumulated physically tiring working conditionsstanding at work, carrying of heavy loads, assembly line work, and considerable physical effort-were related to higher preterm delivery and low birthweight rates.

For preterm delivery, this relation was not statistically significant in each group of occupations. Nevertheless, among manual workers, a higher preterm delivery was observed for women who cumulated several tiring working conditions. For low birth weight, this relation was significant among manual workers and the trend was observed among the other workers. The high percentage of low birthweight babies for women who had to make a considerable physical effort was not totally due to a higher preterm delivery rate, since this finding was observed also when gestational age was taken into account. Other working conditions considered separately and, in particular, standing at work and duration of work, were not related to the outome of pregnancy,

The relation between occupational activity, working conditions, and the outcome of pregnancy have been considered in several studies, ${ }^{9}$ without always a relevant discussion of the methodological issues raised by the type of study. ${ }^{11}$ The occupations for which a high preterm delivery rate has been observed are shop assistants, ${ }^{31213}$ production workers, ${ }^{312}$ and hospital personnel, particularly ancillary staff. $^{3514}$ Working in a standing position ${ }^{3-51213}$ and carrying heavy loads 351415 have been frequently reported as risk factors for preterm delivery. Mamelle et al have also mentioned a higher preterm delivery rate for assembly line workers. ${ }^{3}$ Night work, which has rarely been studied, was not associated with preterm delivery in the survey of hospital personnel carried out in the Paris area between 1979 and 1981. ${ }^{5}$

Generally speaking, physically demanding jobs or cumulated strenuous working conditions are often associated with preterm delivery when it has been considered by the authors. ${ }^{351316}$ A long working week seems also to be related to preterm delivery. ${ }^{3}{ }_{13} 17$

Findings concerning birth weight are much less numerous: data from the national survey carried out in France in 1976 indicated that the frequency of small for dates infants was higher when the mothers cumulated several strenuous work conditions. ${ }^{18}$ Fricker et al have shown that the mean birth weight was lower when the mothers worked full time or when they had a job requiring physical strain ${ }^{19}$; if the first relation was due to the smoking habits of women working full 
time, the second remained significant after adjustment for smoking.

When we compare the findings published in the past 15 years with those obtained in 1981, the latter seem less significant-for instance, standing at work which has often been described as risk factors for preterm delivery did not appear as such in this survey. Since 1976, sickness absences have increased during pregnancy: for all working women, the percentage of those who did not work at all during the third trimester rose from $13 \%$ in 1976 to $25 \%$ in $1981 .^{20}$ The analysis made for employees who worked beyond the first trimester indicates that sickness absences were commoner when the working conditions were arduous, even without any pregnancy abnormality that might have justified an interruption in the activity. When faced with arduous working conditions, sickness absences are often used as a preventive measure, frequently in the form of sick leave prescribed by the physician. If women with arduous working conditions stop work earlier than other women and sometimes very early in pregnancy it is logical that the impact of these working conditions on preterm delivery appears less clearly than when women kept on working later in pregnancy. Nevertheless, the same observation cannot be made for assembly line work, which seems harmful despite frequent sick leave of the women concerned. These results raise the issue of the efficacy of sickness absences considered as a preventive measure against industrial risks, the alternative being modifications of the working conditions.

Changes in the working conditions described by women in this survey may result from industry group agreements or from the application of the 1975 Act. $^{6}$ They may also be informal changes that have required neither the intervention of the occupational health practitioner nor the application of specific regulations. They were less clearly related to arduous working conditions than sick leave; they were not significantly more frequent for standing at work, a working condition known to be a factor of risk of preterm delivery, nor for assembly line work, which had also already been shown as a risk factor of preterm delivery.

Arrangements directly meeting these working conditions, respectively the possibility to sit more often and a reduction in the output norms, were actually more frequent for women submitted to these working conditions although they concerned a low percentage of women only. On the contrary, shorter working hours or additional breaks were not more frequent when the working conditions were arduous; this may be explained insofar as in France shorter working hours have been systematically provided for women working in the public administration or in large companies with mainly clerical work, which does not re- quire the above mentioned conditions.

Refusals to grant favourable arrangements were $\stackrel{\$}{\circ}$ more frequent when the working conditions were tiring: these women more often than others requested a s? modification in their job and they were mostly 0 refused. In many cases this dissatisfaction found ex- $\overline{-}$ pression in sickness absences. This phenomenon hap- $\overline{\frac{\bar{F}}{\bar{N}}}$. pened to a lesser extent for the women who did not $\mathbb{\Phi}$ request changes in patterns of work because they judged them a priori impossible, thus making a re- $\infty$ fusal to their request extremely likely. It is true that $\vec{O}$ some jobs are not easily modifiable, particularly in $\vec{A}$ small firms. Sickness absence used as an alternative to $\tilde{\sigma}^{\circ}$ a refusal for changing the working practices of $\stackrel{\circ}{\circ}$ women working in hospitals of the Paris area has also $\frac{\mathbb{D}}{3}$ been observed. ${ }^{21}$

The issue brought up here is complicated by the number of social partners affected: sickness absencesin are prescribed for pregnant women by physicians on $\omega_{\overparen{N}}$ their own initiative or on a woman's request, whereas을 the decision to change the working conditions is taken by employers with the possible mediation of occu- $\rightarrow$ pational physicians. Doctors in charge of the care of pregnant women have been informed about medical $\vec{\theta}$ risks related to working conditions; in order to pre- $\stackrel{\infty}{-\infty}$ vent these risks they may apply the means at their. disposal-sickness absences-without any effect on their own situation. By contrast, employers, and particularly employers in small firms who are profes-ō sionally less aware of medical risks, cannot modify the jobs of pregnant women without a real cost to $\mathbb{Q}$ their firm. Nevertheless, one may wonder if the $\overrightarrow{\vec{\prime}}$ difficulties raised in the firm by the sickness absences 3 (replacement of staff or loss of profit) are not as im-כ portant as those created by changes in work. Finally, it would be proper to know which solution pregnant $\overline{-}$ women, who are those concerned in the first place, $\stackrel{\mathbb{S}}{\mathcal{S}}$ judge the most desirable. We may think that even if many women appreciate sickness absence some consider this break as having a negative impact for theiro profession; for other women, a wage cut may be a⿳ drawback. In addition to the legal antenatal leave before confinement (six weeks) in the case of patholo-J gical pregnancy an additional two weeks leave is paid $\frac{D}{0}$ for by the maternity insurance: $84 \%$ of the salary up to the social security maximum $(9480 \mathrm{~F}$ on 1 July ज 1986). All other sickness absences are paid for by the health insurance up to $50 \%$ of this salary ceiling when there is no extra private insurance. Furthermore, $\omega$ some changes such as a change of post may be badlye experienced by some women, either because they do을 not need it or because they do not feel like leaving the job and colleagues they are used to.

The respective effectiveness of sickness absences $\frac{T}{0}$ and changes in working conditions in preventing pre- $-\frac{\mathrm{T}}{\mathrm{D}}$

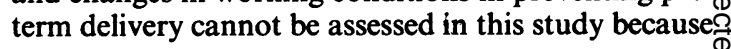


of the study design. Sickness absences may have been prescribed not only as a preventive but also as a curative measure in the case of an abnormality on a premonitory sign for a threatened preterm delivery. We may also wonder if women with abnormalities did not more easily obtain a change in their work; the data collected here could not answer these questions. Moreover, a proper assessment of the efficiency of preventive measures requires specific methods such as experimental studies including randomised trials.

Taking into account the present knowledge on perinatal outcome in relation to the physical burden of work during pregnancy, further research should be directed to find out how physically arduous jobs might be changed: nature, application, and effectiveness of possible arrangements should be evaluated on a medical but also on a social and economic level, including impact on women's employment.

We thank Docteur Claude Rumeau-Rouquette for her advice in this study, Hélène de Coligny for her help in translating the text, and Monique Corre and Véronique Stengel who have typed this paper.

\section{References}

1 Saurel-Cubizolles MJ, Kaminski M. Work in pregnancy: its evolving relationship with perinatal outcome. A review. Soc Sci Med 1986;22:431-42.

2 Chamberlain G, Garcia J. Pregnant women at work. Lancet 1983;i:228-30.

3 Mamelle N, Laumon B, Lazar P. Prematurity and occupational activity during pregnancy. Am $J$ Epidemiol 1984;3:309-22.

4 Murphy JF, Dauncey M, Newcombe R, Garcia J, Elbourne D. Employment in pregnancy: prevalence, maternal characteristics, and perinatal outcome. Lancet 1984;i:1163-5.

5 Saurel-Cubizolles MJ, Kaminski M, Llado-Arkhipoff J, et al. Pregnancy and its outcome among hospital personnel according to occupation and working conditions. J Epidemiol Community Health 1985;39:129-34.

6 Art L. 122-25-1. Code du travail. Paris: Dalloz, 1982.
7 Rumeau-Rouquette C, Du Mazaubrun C, Rabarison Y. Naître en France, 10 ans d'évolution. Paris: INSERM-Doin, 1984.

8 Code des catégories socioprofessionnelles. 6th ed. Institut National de la Statistique et des Etudes Economiques, 1977.

9 Saurel-Cubizolles MJ, Kaminski M, Garcia J. Conditions de travail des femmes enceintes et prématurité. Colloque sur la prévention de la naissance prématurée, Evian, 19-22 Mai 1985. Paris: Institut National de la Santé et de la Recherche Medicale (in press).

10 Rumeau-Rouquette C, Goujard J, Huel G, Kaminski M. Malformations congénitables, risques périnatals, enquête prospective. Paris: Institut National de la Santé et de la Recherche Medicale, 1978.

10a Reed DM, Stanley FJ. The epidemiology of prematurity. Baltimore: Urban and Schwartzenberg, 1977.

11 Joffe $M$. Biases in research and reproduction and women's work. Int J Epidemiol 1985;14:118-23.

12 Saurel-Cubizolles MJ. Influence de l'activité professionnelle de la femme enceinte sur le déroulement et l'issue de la grossesse. Université Paris V, 1979. (Diplôme de maitrise en sociologie.)

13 Saurel-Cubizolles MJ, Kaminski M, Rumeau-Rouquette C. Activité professionnelle des femmes enceintes, surveillance prénatale et issue de la grossesse. J Gyn Obst Biol Reprod 1982; 11:959-67.

14 Estryn M, Kaminski M, Franc M, Fermand S, Gerstle F. Grossesse et conditions de travail en milieu hospitalier. Rev Fr Gynecol Obstet 1978;73:625-31.

15 Papiernik E. Fatigue et résultat de la grossesse. In: Monaco 2. Vers une grossesse sans risque. Courbevoie: Nestlé-Guigoz, 1973:214-20.

16 Papiernik E, Kaminski M. Multifactorial study of the risk of prematurity at 32 weeks of gestation. I. A study of the frequency of 30 predictive characteristics. J Perinat Med 1974;2:30-6.

17 Goujard J. Professional activity and working conditions. In: Sixth European Congress of Perinatal Medicine. Stuttgart: Thieme, 1979:150-5.

18 Saurel-Cubizolles MJ. Activité professionnelle des femmes enceintes, comportement médical et issue de la grossesse. Approche socio-historique et épidémiologique. Université Paris I, 1982. (Thèse en Sciences Sociales de la Santé.)

19 Fricker HS, Bruppacher R. Erwerbstätigkeit während des Schwangerschaft und Geburtsgewicht. Sozial-Präventivmedizin 1984;29:92-3.

20 Saurel-Cubizolles MJ, Kaminski M. Activité professionnelle pendant la grossesse. In: Rumeau-Rouquette C, Du Mazaubrun C, Rabarison Y, eds. Naitre en France 10 ans d'évolution. Paris: Institut National de la Santé et de la Recherche MedicaleDoin, 1984:138-47.

21 Saurel-Cubizolles MJ, Kaminski M, Llado-Arkhipoff J, et al. Déroulement et issue de la grossesse selon les conditions de travail en milieu hospitalier. In: 14 èmes journées nationales de Médecine Périnatale. Angers: Arnette, 1985:318-20. 